\title{
On becoming a practical theologian: Past, present and future tenses
}

\begin{tabular}{|c|c|}
\hline $\begin{array}{l}\text { Author: } \\
\text { Elaine L. Grah }\end{array}$ & $\mathrm{am}^{1,2}$ \\
\hline $\begin{array}{l}\text { Affiliations: } \\
\text { 'Department } \\
\text { Religious Stud } \\
\text { of Chester, Un }\end{array}$ & $\begin{array}{l}\text { fheology and } \\
\text { ies, University } \\
\text { ited Kingdom }\end{array}$ \\
\hline $\begin{array}{l}\text { 2Department } \\
\text { Theology, Fac } \\
\text { Theology, Uni } \\
\text { Pretoria, Sout }\end{array}$ & $\begin{array}{l}\text { f Practical } \\
\text { alty of } \\
\text { versity of } \\
\text { Africa }\end{array}$ \\
\hline $\begin{array}{l}\text { Research Proj } \\
\text { Project Leade } \\
\text { Project Numb }\end{array}$ & $\begin{array}{l}\text { ct Registration: } \\
\text { r: Y. Dreyer (1) } \\
\text { er: } 2546930\end{array}$ \\
\hline $\begin{array}{l}\text { Description: } \\
\text { Prof. Dr Elaine } \\
\text { participating i } \\
\text { project, 'Gend } \\
\text { Practical Theo } \\
\text { Formation', di } \\
\text { Dr Yolanda Dr } \\
\text { Department o } \\
\text { Theology, Fac } \\
\text { Theology, Uni } \\
\text { Pretoria. }\end{array}$ & $\begin{array}{l}\text { Graham is } \\
\text { the research } \\
\text { er Studies and } \\
\text { logy Theory } \\
\text { rected by Prof. } \\
\text { eyer, } \\
\text { f Practical } \\
\text { lty of } \\
\text { rersity of }\end{array}$ \\
\hline $\begin{array}{l}\text { Correspondin } \\
\text { Elaine Grahan } \\
\text { e.graham@ch }\end{array}$ & $\begin{array}{l}\text { g author: } \\
\text { ester.ac.uk }\end{array}$ \\
\hline $\begin{array}{l}\text { Dates: } \\
\text { Received: } 04 \text { I } \\
\text { Accepted: } 24 \\
\text { Published: } 31\end{array}$ & $\begin{array}{l}\text { May } 2017 \\
\text { une } 2017 \\
\text { Aug. } 2017\end{array}$ \\
\hline $\begin{array}{l}\text { How to cite th } \\
\text { Graham, E.L., } \\
\text { becoming a p } \\
\text { theologian: Pa } \\
\text { future tenses' } \\
\text { Teologiese Stu } \\
\text { Theological St } \\
\text { a4634. https:/ } \\
\text { 10.4102/hts.v }\end{array}$ & $\begin{array}{l}\text { is article: } \\
\text { 2017, 'On } \\
\text { actical } \\
\text { st, present and } \\
\text { HTS } \\
\text { dies/ } \\
\text { dedies } 73(4) \text {, } \\
\text { /doi.org/ } \\
\text { 73i4.4634 }\end{array}$ \\
\hline $\begin{array}{l}\text { Copyright: } \\
\text { (c) 2017. The } \\
\text { Licensee: AOS } \\
\text { is licensed un } \\
\text { Creative Comr } \\
\text { Attribution Lic }\end{array}$ & $\begin{array}{l}\text { uthors. } \\
\text { S. This work } \\
\text { ler the } \\
\text { nons } \\
\text { ense. }\end{array}$ \\
\hline Read online: & \\
\hline 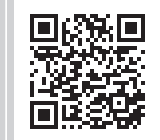 & $\begin{array}{l}\text { Scan this QR } \\
\text { code with your } \\
\text { smart phone or } \\
\text { mobile device } \\
\text { to read online. }\end{array}$ \\
\hline
\end{tabular}

This article takes an autobiographical approach to the development of practical theology as a discipline over the past 30 years, with particular attention to my own context of the United Kingdom (UK). The unfolding of my own intellectual story in relation to key issues within the wider academic discourse provides an opportunity to reflect on some of the predominant themes and trends: past, present and future. Changing nomenclature, from 'pastoral studies' to 'practical theology', indicates how the discipline has moved from regarding itself as the application of theory into practice, into a more performative and inductive epistemology. This emphasis continues to the present day and foregrounds the significance of the human context and the realities of lived experience, including narrative and autobiography. Whilst the methodological conundrums of relating experience to tradition and theory to practice continue, further challenges are beckoning, including religious pluralism, and so the article closes by surveying the prospects for a multicultural practical theology.

\section{Approaching practical theology autobiographically}

In responding to an invitation to make a contribution to a Festschrift to celebrate the life and work of such an eminent scholar as Yolanda Dreyer, it seems appropriate to approach such a task autobiographically because on such an occasion one's mind turns to the convergence of 'life' and 'work'. In recent years, practical theology has undergone something of a turn to the self, a move which, as I shall argue later, is the latest in a number of re-orientations: from applied theology to theological reflection on practice; from a clerical paradigm to the study of the religious practices of everyday life; from theology as propositional knowledge to practical wisdom.

As one way of thinking myself into this project, I have chosen to begin by locating myself, and to consider how my own personal and intellectual autobiography has intersected with the development of the discipline of practical theology: past, present and future. I find myself, then, reflecting on different levels of my own history, as well as various understandings of the nature of practice and what renders that 'theological': my own personal faith journey; my pedagogical and supervisory practice in helping new forms of knowledge to emerge, including practice-based research in theological studies; and what it means to consider the realms of practice and experience as theologically significant - as ways of 'talking about God'. I offer these reflections as a contribution to the continuing conversations within the community of discourse that is practical theology.

\section{Past tense: A quest, a cause and a profession}

Perhaps I have always been a practical theologian, even though my introduction to formal academic theological studies did not take place until I began postgraduate study in what was then called 'Social and Pastoral Theology' at the University of Manchester in the mid-1980s. My own personal Christian formation took place during my undergraduate days, within the Student Christian Movement (SCM). Historically, SCM emerged out of the student overseas missionary societies with their emphasis on promoting vocations of service (Boyd 2007; Tatlow 1933). It was at the forefront of the modern ecumenical movement whose watchword was, 'Doctrine divides but service unites' (Wainwright 2005): a hope that despite denominationalism and disunity, the churches could advance in a common cause of practical witness to society, and that the causes of social reform, justice and human welfare were living expressions of the Gospel.

When I later worked for SCM in England in the early 1980s, recruiting new members and supporting local groups, I saw as lying at the heart of my work the task of enabling students to think about their faith, to apply to their Christian commitment the same kind of rigour and seriousness they would adopt with their academic studies. From those early experiences, possibly, were sown many of the seeds of my subsequent attraction to practical theology: a concern for the 
practical and ethical dimensions of religion; a conviction that there are no 'no go' areas for Christianity, intellectually or materially; that even if the beliefs of a divided Church may compromise its credibility, its authentic mission is to be found in its practices of service and justice; and a sense that there are no easy answers, only that the journey of enquiry has to be rigorous and self-critical.

\section{What's in a name?}

My first degree had been in social science, so when I enrolled on my MA, I wondered whether a lack of undergraduate systematic theology would put me at a disadvantage. In fact, I discovered that many of the skills and conceptual frameworks I already had were well suited to the 'Manchester school' of practical theology, which valued the empirical and experiential as foundations for theological understanding. The view was that serious contemporary theological engagement needed to respond to the questions posed by the world around us. This included the challenges of the human life cycle, broader issues of identity in the face of questions of power and difference (such as sexuality, gender and race), a desire to root theological reflection in its wider economic and social contexts, a growing awareness of the impact of globalisation, and so on. At that time, too, I think I was catching the wave of two important moments in the development of practical theology in the academy. Superficially, they were evident in the changing nomenclature of the discipline, but this also represented a significant shift in self-understanding as well.

\section{From 'pastoral studies' to 'practical theology'}

For most of the twentieth century in the UK, pastoral or practical theology was identified with training for ordained ministry - such as clergy handbooks on the conduct of pastoralia - or as derivative of psychotherapy, focusing on pastoral care, using humanistic principles that were often derived from Christian theology such as unconditional positive regard but which generally had lost touch with the practices and doctrines of Christian tradition.

There were, however, signs that new perspectives were emerging. In an article entitled 'Pastoral Theology: Towards a new Discipline' (Dyson 1983), Tony Dyson, who was to become my doctoral supervisor at Manchester, was beginning to construct a fresh agenda. Whilst it was a relatively brief and speculative intervention in many respects, it proved highly influential in advancing the debate. Dyson (1983) argued that the vogue within pastoral ministry training for forms of psychotherapeutic training was 'symptomatic of the search for a trouble-free zone of inwardness' (p. 20) in which awkward questions about the authority of Scripture, tradition and church practice upon contemporary ministry could be suspended and ignored. Similarly, the predominance of the 'apprenticeship' model of pastoral training for clergy reinforced a certain lack of rigour or openness to fresh ideas or forward thinking. The urgent and vital challenges to the churches of secularisation and cultural pluralism, economic and social injustice, even questions about personal identity and the self, were submerged under the weight of what Dyson called 'warm personalism' (Dyson 1983:3). Presciently, too, he warned that the male-dominated nature of the Church and of the theological canon itself required a thorough-going reconstruction of core beliefs and assumptions regarding the human person, the nature of power, spirituality and care in favour of more inclusive, rigorous and progressive understandings.

Conscientious student that I was, I adopted Dyson's agenda for myself and took it further. My master's dissertation examined the lack of attention to the pastoral needs of women in the literature, concluding that its dominance by a clerical, androcentric paradigm silenced the voices and lives of women (Graham 1989; 1990). In my doctoral work, I addressed Dyson's speculation that huge areas of theological understandings about the human person remained almost completely unexamined. So for example, in the debate about the ordination of women to the priesthood (in the Church of England and Roman Catholic Church), I questioned what it meant to say that women priests would bring 'feminine' qualities to ministry. It seemed to me that this was importing all sorts of assumptions about gender difference and identity that were largely unexamined and undertheorised (Graham 1989; 1990). It revealed a need to interrogate the deeper questions and underlying presuppositions - in other words, to become more sophisticated and self-critical about the concepts and 'regulative ideals' shaping pastoral ministry and other aspects of the Church's life. Subsequently, my PhD was an attempt to interrogate what different disciplines were saying about gender identity, gender roles and gender relations, and what the implications might be for the way theology talked about what it means to be human (Graham 1995).

My own emerging research interests reflected a wider disciplinary reorientation away from 'pastoral studies' to 'practical theology'. In time, my insights were also instrumental in helping to make the transition beyond the therapeutic and clerical paradigms, bringing a more robust theoretical framework to bear and undertaking a more searching investigation into the conditions under which the 'action-guiding world views' of Christian communities were actually engendered. This also entailed a move away from a primary objective as training for ordained ministry, towards an investigation into the whole church as a community of practice. Increasingly, this was understood as the context in which 'ministry' of many kinds took place, from Christian formation and nurture, to worship, to pastoral care, to community engagement and outreach, to public statements on social issues.

\section{From 'applied' to 'practical' theology}

This was also a time of a shift away from the language of 'applied' theology (although it is still something one encounters) to that of 'practical' theology. This was part of a questioning of an established curricula pattern which began ministerial formation with the study of doctrine, 
Church history and Bible and only subsequently thinking about practice, often post-ordination, via odds and ends of pastoralia, or 'hints and helps' (Hiltner 1958).

Debate also centred on the legacy of Friedrich Schleiermacher (1768-1834), often credited as the founding figure of modern practical theology, whose characterisation of theological studies as a tree in which philosophy formed the roots, Church history the trunk and practice the branches, reinforced a hierarchy of knowledge which privileged 'theory' over 'practice' (Campbell 1990). Instead, by the 1990s, the literature in practical theology was talking increasingly about a project of beginning with and from practice and experience:

... from practice to theory and back to practice ... Or more accurately, it goes from present theory-laden practice to a retrieval of normative theory-laden practice to the creation of more critically held theory-laden practices. (Browning 1991:7)

Similarly, the influence of the theologies of liberation, with their emphasis on beginning with the everyday issues of life as the foundations of theological reflection, was absolutely crucial in the task of turning theology on its head so that experience and practice informed doctrine, and not the other way around (Graham 1996; 2000:108-109).

Practical theology came to be more clearly distinguished from its systematic sibling, which was about 'the ordering of beliefs about God, the church, or classic texts' (MillerMcLemore 2011:14). By contrast, practical theology was finding a disciplinary coherence in the very theological nature of practice, whether those were explicit practices of faith, or the routines and rituals of everyday life, and whether they were Christian, non- or post-Christian, institutionalised and informal. Practical theology was beginning to think of itself as 'a primary, performative religious activity that happens in and through ordinary adherents, and often by means of their practices' (Nieman 2002:202).

The pastoral disciplines of personal care, social action, worship and initiation were thus achieving a renewed currency, as more than the 'applied' offshoots of a body of propositional theory that transcended the contingency of human activity. Rather, the ways in which Christians choose to organise their ways of being in the world - relating to one another in community, and of enacting ritual, care and spirituality - were held to constitute the language of authentic identity. Practical theology, therefore, functions in order to enable communities of faith to 'practise what they preach' (Graham 2000:106). The task of the critical practical theologian is to examine how (embodied) pastoral practices constitute a 'Christian' (or faithful) identity - an identity which is always already performative (Graham 1996). If theological values have any substance, they will exist in primary form as bodily practices - in activities of care, worship, proclamation, transformation - and only derivatively as doctrines and concepts. Practical theology essentially gives voice to the 'body language' of the Christian faith. Pastoral practices are sacraments of the divine at work in human relationships, and the vocation of the Body of Christ is thus to 'become the flesh of our words' (May 1995:88):

... the specific practices by which we respond to God's grace practices such as prayer, forgiveness, and hospitality - bear knowledge of God, ourselves and the world that cannot be reduced to words, even though words are often important in helping us to learn and participate faithfully in them. Such practices embody certain kinds of wisdom and foster certain kinds of intelligence when engaged in serious and critical ways. (Bass \& Dykstra 2008:358)

Increasingly, then, throughout the 1990s practical theologians moved away from the language of 'applied theology' to describe their work, in favour of terminology such as 'practical wisdom' (Bass et al. 2016; Browning 1991; Graham 1996). All theology is 'practical' because it serves as the 'compass' for our lives together: orientating our aspirations and actions about justice, flourishing, community, forgiveness, the fruits of the spirit in the living reality of God. Doctrine emerged historically not for its own sake but in order to give shape to Christian discipleship - to provide the words that enabled and gave life to faithful action. Theological understanding is not an abstract principle awaiting application in practice or as it 'translates' from theory into action. It is always already 'embodied, situated knowing-in-action' (Bass et al. 2016:2).

\section{Present tense: Some staple precepts of practical theology}

It is instructive to see how these emerging ideas have developed over the past 30 years and have created a number of the characteristic preoccupations of our contemporary discussions.

\section{The relationship of theory to practice}

Eric Stoddart (2014) characterises practical theologians as 'bidirectional':

\footnotetext{
... Practical Theologians are congenitally more comfortable with the notion of two-way rather than one-way streets. Practical Theologians will ... hold that people's practice is informed, shaped, perhaps, by doctrine - or even dictated by it. But ... Practical Theologians want to keep asserting that doctrine is informed, shaped and even dictated by practice. (p. xii)
}

Practical theology regards practice as significant in a number of ways. Firstly, this emphasis on practice is intended to foreground the significance of the human context and the realities of lived experience as the domain in which Christian ministry or action takes place. Practice denotes the 'embodied expression of particular kinds of knowledge' (Stoddart 2014:3). Whereas 'practice' may denote something quite routinised and unreflective, the term 'praxis' points towards something that is more reflexive, that is both value-directed and value-laden. It is the meanings we bring to practice and the meaning-making associated with our actions.

And that takes us to a second dimension of why theology is practical. Theology is practical, but practice is also 'theological' - 
'practice is taken to be theologically significant' (Beaudoin 2016:9). This is why it differentiates itself from anything approaching 'applied' theology because theology does not simply end in practice, but begins there as well. No theologian is going to admit to their theological study as being 'impractical' in the sense of having practical bearing, but what really differentiates practical theology is, I believe, this second turn to practice as the source and origin of theological understanding:

$[T]$ heology [is] a practical discipline. It is the intellectual reflection on the faith we share as the believing community within a specific cultural context. But it has as its goal the application of our faith commitment to living as the people of God in our world. (Grenz 1993:17-18)

In the work I did with Heather Walton and Frances Ward in the early 2000s, our aim was not so much to produce a handbook for exercises in theological reflection as to recontextualise the history of Christian doctrine and put forward just such a manifesto for regarding all theology as practical - from start to finish. So we argued, on the one hand, that theological discourse begins (and ends) in practice: theology itself is engendered by the imperatives of discipleship and lived experience (Graham, Walton \& Ward 2005). Historically, certain key practical challenges and tasks prompted the need to construct a Christian world-view:

- initiation and nurture, or the formation of character

- circumscribing the boundaries of belief, or building communities of faith

- communicating the gospel to the wider world (Graham et al. 2005:10-11).

However, this consolidated further (as I had begun to do in Transforming Practice, 1996), into a sense that these lived experiences and faith practices actually constituted a kind of 'performativity' in respect of theological truth-claims. This is the third movement of practical theology: not just to say that theological adequacy is tested in practice or as it translates into action, but that theology is primarily performative and enacted, and only secondarily or derivatively written down and systematised. Here, the influence of postmodern and liberationist thinking is notable: theology is practised as orthopraxis first, and systematised as orthodoxy second (Graham 1996; 2000). Theology is sacramental, incarnational and enacted: it is talking about God as embodied in faith-filled practices:

The aim of theology is not to work out a system that is enduring so much as to meet everyday experiences with faith - and to express that faith in terms of everyday experience. Theology is an ongoing process. It is the habitus of praying Christians, of reflective ministers, and believing communities. (Bevans 2014:49)

Trying to understand human action and thought and the meanings inherent in practice - including their theological bearings - requires sophisticated methods of enquiry and interpretation. In turn, how these meanings constitute 'action-guiding world views' for their actors - and whether one rests with a descriptive account or moves into normative and transformative mode - draws one back to the world of actions and practices. So whilst most practical theologians would sign up to Don Browning's characterisation of 'practice-theory-practice' it is by no means straightforward. We need to see how practices are always theory-laden, and theory, or concepts, or doctrines, are themselves forms of meaning-making that serve practice.

If this is the case, then to be a practical theological researcher is to enquire into these embodied expressions of situated knowledge. This implies taking context seriously - hence Paul Ballard's call to attend to 'the concrete, historical and immediate reality' confronting the Church, in order 'to equip the People of God in the service of the world' (Ballard 1992:5).

\section{Interdisciplinarity}

Interdisciplinarity is constitutive of practical theology. (Mercer 2016:163)

This leads me to the next distinctive quality of contemporary practical theology, as characterised by its dialogue with other theological and Biblical disciplines, as well as the social and human sciences. Given the contextuality and complexity of the field of study, it is perhaps inevitable that practical theologians should argue that no single methodology or interpretative framework is able to do such a process of enquiry justice. Practical theologians, therefore, have to call upon a variety of research methods and tools. Furthermore, the researchers are themselves embedded in and complicit with the field of activity to be studied:

The primary locus of theology is not academia nor even ecclesia, but human history as it unfolds in the world ... This means that the praxis of God in history as it is co-constituted through human praxis is our primary text and context for doing theology. And because the whole created order and the activity that constitute human history are potential disclosures of God to us, then all the human sciences, disciplines of learning, and ways of knowing are potential resources for our theologizing. (Groome 1987:61)

As Joyce Ann Mercer observes in her discussion of my work on theological anthropologies of advanced, 'post-human' technologies, a willingness to locate oneself at the 'intersections' of discourse can bring a refreshing openness to new theological meanings (Mercer 2016:227-228). Equally, however, there are corresponding risks, such as incoherence or naivety in the face of complex and diverse bodies of knowledge. Even more controversially, a commitment to interdisciplinarity within practical theological method represents, for some, a dilution of the explicitly theological voice. This locates us on one of the chief fault-lines of Christian tradition and theological study, which is the question of the relative status and authority of tradition versus experience; or of the balance between theological and non-theological sources and norms. As the early Christian writer Tertullian (1956) was reputed to have asked:

What indeed has Athens to do with Jerusalem? What concord is there between the Academy and the Church? What between heretics and Christians? Away with all attempts to produce a mottled Christianity of Stoic, Platonic, and dialectic composition! We want no curious disputations after possessing Christ Jesus, no inquisition after enjoying the gospel! (p. 36) 
As this famous passage suggests, Tertullian was opposed to any kind of accommodation to pagan philosophy, which is a strand of theological thinking that continues to this day. It is perhaps represented in twentieth-century theology by the Swiss theologian Karl Barth (1886-1968) who was sceptical of liberal Protestantism's optimism towards the self-evident advance of modern civilisation and the capacity of human reason to discern the truth. For Barth, salvation came not from human wisdom but from divine self-revelation alone, in the form of the Word made flesh in Jesus Christ. Such revelation transcended and erupted into human culture (Barth 1928).

This is often seen as in direct contrast to practical theology's emphasis on experience and interdisciplinary attention to the world - whether that is the narrative self-disclosure of Anton Boisen's 'living human document', or Schleiermacher's faith in the universal instinct of human religious experience, or the liberationists' emphasis on the imperatives of the world's injustices as constituting the primary text of theological study. Certainly, the tension between the inductive and the deductive within practical theology, which was perhaps submerged in the latter part of the twentieth century when liberal and correlationist perspectives tended to hold sway (Pattison \& Lynch 2005), has re-surfaced in recent years - an issue to which I shall return shortly.

\section{The reflexive turn}

We are beginning to come full circle, to the autobiographical or autoethnographic nature of much contemporary practical theology (Beaudoin 2008; Bennett and Rowland 2016; MillerMcLemore 1994; Pattison 2000; Stoddart 2014; Walton 2015). This 'reflexive turn' in practical theology mirrors similar trends across the humanities and social sciences. Insights from the sociology of knowledge, including postmodern and feminist perspectives, have cast doubt on epistemologies that lay claim to neutrality and objectivity, insisting on critical attention to the material and ideological circumstances within which claims to truth are constructed (Harding 1991). This calls for a greater degree of transparency on the part of the researcher, and is formalised in disciplines such as action research (Stringer 2007) and forms of reflective practice (Moon 2006; Schön 1983) by which the processes of formation and reflection can be more closely charted and interrogated. Such an approach repudiates the belief that research can be conducted through a long lens, as it were, in such a way that the researcher themselves is unaffected by the process. Certainly within the social sciences, such strict objectivity is untenable; anyone dealing with the realms of human value, meaning and understanding recognises that levels of interpretation are unavoidable; research methodologies take account of the 'storied' and hermeneutical nature of human culture. This is not only an individual process of formation but also one that is shared within particular communities of practice.

It is not about reducing practical theology to autobiography but seeing how our own standpoints and concerns have informed our intellectual and academic interests, and vice versa. In the interests of integrity and transparency, the self as researcher, as one who brings particular presuppositions, questions and interests, must be prepared to 'write themselves in' to the text of their research. This practice of locating and declaring ourselves is not simply a question of stating who we are as a set of statistical or physical facts, or of inflicting our personal life histories on a captive audience. It involves being aware of one's own pre-commitments, and how the practices of research may in themselves be challenging or reshaping one's own relationships to the field. It entails more than simply 'reflecting' in the sense of thinking deeply about something, but of identifying how we are simultaneously both the subjects and objects of our own experience. It is to apprehend ourselves not just as the authors and subjects of our lives, but as the objects of factors (historical, familial, social) that pre-date our births; and to train ourselves in the techniques of being able to turn the mirror of reflection back on ourselves - almost to see ourselves coming back. In turn, the practices of opening that out to scrutiny - journalling, autoethnography, spiritual life writing - become part and parcel of the researcher's tool-kit (Walton 2014:xxxi-xxxiii). 'Reflection' and 'reflexivity' are thus closely allied but differentiated:

... reflective processes are characterized by acute observation and analysis of roles and context. Reflexivity takes this critical work a step further and also interrogates the position of the 'self' who observes. (Walton 2014:xii, n.1)

'My story', then, is more than simply an account of events, but instead an artifice constructed in order to represent myself back to the world and to myself. The reflexive self acknowledges the conventions of that representation and how it can contribute to greater self-knowledge and understanding. Furthermore, a reflexive, transparent and autobiographical approach to practical theology is essential if it is truly to be liberated from the hegemony of abstract reason and the privileging of theory over practice, as Bass et al. argue (2016). In seeking to commend and expound practical theology as 'practical wisdom', they begin from the precept that theology is first and foremost performative. The life of faith is pursued in everyday situations, and what they term 'the intelligence of practice' (2016:1-19) is enacted as people draw upon and inhabit their traditions. Yet these traditions are not simply doctrinal or propositional, but embodied in practices: of praying, eating, creating, making and communicating (Bass et al. 2016; see also MillerMcLemore 2011). Bass et al. (2016) insist on demonstrating this by intentionally beginning with the practices of everyday life and writing about 'concrete situations where the kind of engaged, embodied knowing that belongs to discipleship is visible' (p. 16).

Similarly, introducing his 2014 book, Advancing Practical Theology, Eric Stoddart tells his readers, 'I want to crave your indulgence for an autobiographical account' (Stoddart 2014:1), and proceeds to tell the story of his journey towards being able to self-identify as a practical theologian. It is interesting that he feels obliged to begin like this, with an 
apology, and a need to seek permission. It suggests, perhaps, that the weight of academic convention is still inclined to discount personal experience and to suspect those who refuse to 'leave themselves off the page' (Graham 2013:9).

Yet Stoddart chooses to utilise his own story as a critical lens through which to examine some of the chief facets of his evolving understanding of, and engagement with, the discipline of practical theology as he encounters it in a number of different contexts. He uses the device of journeying, in which a trip to South Africa becomes pivotal in stimulating other shifts - religious, professional, intellectual, emotional. His recounting of this journey then becomes (to mix metaphors a little) a mirror that is held up in order to subject himself to critical scrutiny. He portrays it as a process of transformation: a movement from a relatively conservative and traditional theological position towards a different, more open, stance. In the process, he comes to affirm certain precepts, such as an emphasis on divine revelation through human experience as well as revealed tradition; the need to place practices of personal and pastoral care within broader socio-economic factors; and how faithful reading of sacred texts must be accompanied by careful and searching attention to one's context. But these realisations came to him in pieces, as it were, and it was only as he began to be more deeply immersed in the world of practical theology that he could see how as a discipline it enabled him to make sense of these fragmentary episodes of his emerging 'critical discipleship' (Stoddart 2014:xv).

In a remarkable collaboration between New Testament scholarship and practical theology, Chris Rowland and Zoe Bennett have developed some striking perspectives on the nature of seeing, reflection and discernment in relation to the production of knowledge. In considering how one may strive for greater self-understanding, awareness of one's own location - social, economic, cultural, ideological - is a necessary step on the road to what they term 'critical subjectivity' (Bennett \& Rowland 2016:151). Bennett and Rowland contrast the fixed, solipsistic gaze of Narcissus at his reflection in the lake in Caravaggio's famous painting with the more distorted, fluid and multidimensional images occasioned by looking onto the surface of 'the Bean', a famous urban sculpture in down-town Chicago. Rather than assuming reflection to be a simple matter of holding up a mirror to nature, we may acknowledge that it is more a question of choosing to see 'through a glass darkly' in ways which acknowledge our hidden biases and yet locate ourselves more authentically. 'We are bound to see and understand partially; it matters to know what the 'parts' are that we are seeing, and how our way of seeing both reveals and distorts' (Bennett \& Rowland 2016:3-4). To see - to judge to act: at the heart of this is critical reflection on ourselves and our situation, allowing different elements of our context to illuminate one another:

To see your own reflection is not necessarily to know the full 'truth' about yourself; nor is seeking to see your own reflection always a safe practice ...
Furthermore, the image of looking into a pool of water, or a bedroom mirror, is too simple to denote the practice of reflexivity. Anyone who has visited Chicago and seen Anish Kapoor's 'Cloud Gate', popularly known as 'the Bean', will have seen a vastly more complex form of 'self-reflection'. In this massive sculpture with a highly reflective surface of seamless stainless steel plates, curved and shaped like a bean, your reflection is distorted by the curves and given a context within the alsodistorted reflections of the crowd, the clouds and the skyscrapers of down downtown Chicago. As you move and look from another angle your own reflection changes. People take pictures of themselves taking pictures of themselves, taking pictures of themselves. The process of self-reflexivity is infinitely regressive. The more clarity the more mystery, leading to more clarity and thence to more mystery. This is the heart of the ongoing task of self-reflexivity. (Bennett \& Rowland 2016:152)

Certainly, practical theology is growing in confidence to state its own implicit values - such as by adopting forms of action research in which the location and subjectivity of the researcher and a commitment to broadly transformative, collaborative and egalitarian ends are clearly stated. This turn to reflexivity thus represents an attention to the contextual and autobiographical nature of practical theological knowledge. Yet it also signals an emerging emphasis on the everyday narratives and practices of faith, as they are read inductively for what they reveal as enactments of theological worlds or truth-claims. This may reflect in part the deinstitutionalisation of post-secular Christendom, the decline of institutional religion in the West and its mutation into expressions of grassroots, informal spirituality. It may also reflect, culturally, a renewed, but more sophisticated, form of personalism, with an emphasis on subjectivity, conscience and personal experience (post-Schleiermacher) as constituting the essence of religion. This shift to practical theology as the 'hermeneutics of lived religion' (Ganzevoort \& Roeland 2014:99, n. 30) may, therefore, presage a further, long-term, relocation of practical theology moving beyond creedal, organised Christianity into the terrain of wider cultural practices.

\section{Future tense: Current and future challenges Sources and norms}

I have already hinted at this particular contention within contemporary practical theology. Increasingly, scholars are asking how practical theology is different from the social sciences or other fields of professional training. Whilst there would be consensus amongst all practical theologians as to the theological and values-based nature of their pursuits, quite what that looks like is more controversial. Certainly, given our concerns for practice, we feel an accountability for the outcomes of our research; we hold particular views about the importance of human flourishing and wish to nurture forms of action that contribute towards the values.

But beyond that, there is some dispute as to how far the sources and norms of Christian tradition in all its forms should set the agenda for the way these values are articulated. 
Over recent years, this has emerged as one of the most debated areas within practical theological research. For a long time, the predominant position in practical theology has probably been the liberal-correlationist perspective. This would argue that theological understanding emerges dialogically from many different sources: the received and historic tradition, cultural context (such as science, philosophy, the arts or human sciences); and personal or communal 'experience'. This position is associated with Paul Tillich and David Tracy. Stephen Pattison's appropriation of the revised form of critical correlation (Pattison 1989) draws on the idea that theology is comprised of many different sources and that material from the social sciences, popular culture, literature, non-Christian philosophical and psychological insights, feminism and other disciplines provide significant insights and correctives to the repositories of faith:

The underlying methodological position within mutually critical correlative models is that theological truth is emergent and dialectical and as such requires partnering with other sources of knowledge that will enable clarify and revised ecclesial practices ... Within the method of mutual critical correlation, the primary task is therefore to initiate a two-way conversation between the social sciences, in this case ethnography and theology, with both partners open and willing to listen and respond to the insights gained from the other. The division of labor between the two is assumed to be more or less equal ... At one level this seems fine. It opens up the opportunity to challenge aspects of Scripture and tradition that may have become distorted, forgotten, or deliberately overlooked. (Swinton 2012:86)

However, critics of this perspective have argued that in adopting this kind of interdisciplinarity, theology is implicitly offering itself as a hostage to alien, non-theological world views for its account of 'reality'. It will find itself accommodating to suit these presuppositions, such that human horizons and perspectives overshadow God-given principles. Instead, theology must always be normative and responsible for establishing the 'first-order' claims about any given situation. This alternative perspective has been influenced by forms of post-liberal or confessional theologians, such as Karl Barth and his 21st-century heirs such Stanley Hauerwas and John Milbank. Here, there is a greater emphasis on the distinctiveness of Christian identity. The practices of the church, attested to in Scripture and tradition, form a distinctive polity through which theology engages the world. Practical theology is primarily concerned with the practices of the church and with theological renditions of the human condition.

An example of this in practical theology in the UK would probably be the work of John Swinton and Harriet Mowat, who regard practical theology as a conversation between different sources and norms, but conclude nevertheless that theological tradition as received must be afforded primacy over experience. As they say, 'qualitative research tells us nothing about the meaning of life, the nature of God, cross, resurrection or the purpose of the universe' (Swinton \& Mowat 2016:89). Yet this seems to me to over-state the case.
Is it really true that the world beyond the church is devoid of meaning? Can there really be no correlation, critical, mutual or otherwise? Even if we consider tradition to be normative, which and whose interpretation of it; can it be considered such a monolith?

The new Ecclesiology and Ethnography group probably represent a more modified version of this view within practical theology, with their call for researchers to declare their theological presuppositions and objectives. In many respects, the emergence of this network is a reflection of the huge growth in practical theology over the past 30 years, and especially the explosion of interest in qualitative research, beginning in congregational studies and moving into other forms of ethnography, or participant observation (Ward 2012:6-9). Representatives of this strand insist on the presuppositions and pre-commitments of the researcher. Their objection is that practical theology has appeared to use ethnography as a methodological tool within a qualitative vacuum, whereas they envisage that fieldwork is always conducted from within 'a traditioned ecclesial expression' (Ward 2012:3). The practical theologian is more than a disinterested or neutral observer; rather, he or she is involved in a form of ecclesial service in being able to interpret the church back to the church and ensuring that practice is theologically informed. There is frequently too much distance between the 'theological representation of church and the lived social reality of Christian communities' (Ward 2012:5). But this has to be a process of ethnographically driven representation that is itself formed by Christian tradition. This entails '... a constant interaction between theories and principles generated from the theological tradition, and careful participative observation of the particularities of an ecclesial situation' (Ward 2012:2).

This may seem uncontroversial, except it seems to me to be in danger of surrendering the independence of practical theology as merely the service of the Church. There is a risk we end up reinscribing an exclusively ecclesial mindset or the 'clerical paradigm' (Farley 1983), which reduces practical theology to, and conflates it with, ecclesiology - and thereby limits its critical independence, at the expense of both its academic freedom and the hard-won critical perspectives of liberationist, feminist, black, Womanist and queer theologians over the years. Practical theology cannot be reduced to some kind of 'Christian sociology' which (1) assumes hard-andfast ecclesial boundaries or (2) imagines that lived reality is somehow a rendition of doctrinal propositions. This may actually do a dis-service to our context of study, by inhibiting our critical apprehension of the novelty or improvisatory nature of practice and reinscribe regressive models of 'tradition'. The reality is, however, that most ethnography, at macro-level and micro-level, is 'messy' (Ward 2004) because people's lived experience and practice is highly heterodox and characterised by 'blurred encounters' (Baker \& Reader 2009) across boundaries of faith, identity and belief.

Certainly these kinds of critiques of the correlational position helpfully expose the extent to which all researchers bring values into the conversation and to which all disciplines, and 
not just theology, are value-laden. But it is something of a misrepresentation of liberal correlational theology to say that it has simply been practising a kind of naïve realism whereby it does not process the accounts it receives from social analysis through an evaluative filter. It is not accurate to claim that in valuing the concrete, empirical and contextual by undertaking qualitative inquiry using social scientific tools, practical theology loses its right to be called Christian or inevitably capitulates to a form of methodological atheism.

In reality, then, Christian identity, practice and belief have always developed in constructive engagement with the cultures in which these have been embedded. Indeed, Christian identity itself is not 'a matter of unmixed purity, but a hybrid affair established through unusual uses of materials found elsewhere' (Tanner 1997:152).

This is not a new debate, as the age-old tension between the 'secular' wisdom of the Athenian academy and the theological tradition of the faith-communities of Jerusalem attest. Even liberation theologians, however, identify that there needs to be a 'pre-commitment' to the Gospel before anyone can engage in (Marxist) social analysis (Boff \& Boff 1987:22-23). So as Zoe Bennett argues, this is not a straightforward choice between 'the text of the Bible' and 'the text of life', in which each fears the 'tyranny' of the other (Bennett 2013:134). Instead, we probably need to move beyond the simplistic and static binary of 'correlation between the Christian tradition and contemporary experience' (Miller-McLemore 2011:17), to consider how, in specific cases, all the inherent values and world views in a situation are constructed within a dialectic of sources and norms, both religious and secular.

\section{Cultural pluralism and multiculturalism}

It is threatening for many practical theologians to imagine releasing a Christian center for practical theology, but that is exactly what confronts us, with no guarantee of what comes next. (Beaudoin 2016:12)

In expressing this sentiment, Tom Beaudoin is identifying a further, as yet uncharted, frontier in practical theology: that of inter-faith dialogue. He argues that practical theology has been heavily invested in constructing and perpetuating what he terms 'Christianicity', or the citation of dominant Western norms and understandings of what may count as legitimately and authentically religious. This translates into the effacement of expressions of Christianity from the global South, but also a resistance to consider how far practical theology can cross the boundaries of other religions:

Practical theology is still quite far, in general, from being able to relate with the depth of creativity and criticality to its Christian heritage that a postcolonial, two-thirds-world-attentive global situation requires. (Beaudoin 2016:18)

So does that present practical theology with a new challenge, to properly face up to such a religious and cultural pluralism? As a community of researchers, should we be looking to develop a multifaith practical theology that fully addresses traditions other than Christianity? This is a long way from
Ecclesiology and Ethnography, of practical theology in the service of a specific faith community. Can it be done? What would be the merits of it?

Any adequate response will not be achieved by simply striking out the nomenclature of 'Christian' and attempting to insert a new religious label in its place, in some kind of 'cut and paste' exercise. For a start, what each tradition counts as authoritative and significant in terms of its key sources would vary. In Jewish and Muslim traditions, for example, much of what Christians would consider under the categories of 'pastoral care' or 'ministry' would better be cast in terms of judicial interpretation of legal tradition. On the other hand, there is some literature within Judaism that deals with leadership in congregational and voluntary organisations: rabbinic ministry as pastoral care, liturgical and ritual presidency; teaching and instruction in the faith. But how far is that a tradition that has actually been partially 'Christianised'? Similarly, whilst Buddhist practitioners warm to the emphasis on the practices of faith - meditation, mindfulness, discernment and so on - it's not easy simply to transpose its many and heterogeneous traditions and texts into a body of knowledge.

In a recent article speculating on the prospects of an Islamic practical theology, Nazila Isgandarova argues that there is scope for an approach that takes account of the lived experience of faith; that considers how tradition (however conceived) shapes contemporary practice; how the presentday lived experience of diverse diasporas are having a bearing on traditional customs; and how enquiry into specific ways of life at the grass-roots feeds back into scholarly traditions of hermeneutics and textual interpretation. She is essentially calling for a move from a primarily textual tradition into studies of the praxis of faith that is embodied in such staple practices as pastoral care, spiritual direction and Islamic education:

The question is how practical Islamic theological studies may help Muslim religious leaders and clergy to connect their theological understanding to the everyday experience of Muslims in the community, society and the world. The second question ... relates to the daily life practice of Islamic faith and tradition: 'How do the daily life practices gain an "epistemic weight" in the production of new knowledge in practical Islamic theology, where Islamic doctrine, tradition, and the "living human document" hold a central position?' (Isgandarova 2014)

Isgandarova points to Muslim chaplaincy work in public institutions as one of the places where a new sensibility can be generated. Similarly, Asgar Rajput, a British prison chaplain, has argued that Muslim presence in chaplaincy contexts has tended to proceed along the lines offered by Christian structures and presuppositions that are based on paradigms of ministry, theology and community. However, these have not necessarily been particularly productive or creative. Instead, Rajput argues for a new, emergent model to develop, a 'hybrid' version that is based on a synthesis of institutional demands, Islamic theology, the realities of public perceptions of religion (at the moment heavily dominated by fears of radicalisation) and the practical needs of the umma (Rajput 2015). 
Certainly, then, a religiously plural practical theology will not simply be an extension of Christian practical theology. There will need to be some kind of common forum created in which many different traditions can converge - but is that yet possible on equal terms? Certainly, there are many places in which dialogue might take place; and such a process might indeed begin with the current emphasis of Christian practical theology upon truth as performative and pragmatic. The shared realms of activities such as broad-based and community organising, advising on religious literacy and promoting social justice and human rights, and places such as chaplaincy, might offer the most creative opportunities for such rapprochement. Maybe those things have to happen outside the recognised centres of power such as academy or male-dominated hierarchies. It may not yet be possible to predict yet where those conversations are taking place, and where they might lead. I wonder, however, whether the future of multifaith dialogue in practical theology might actually begin, as with the early ecumenical movement over a century ago, not in attempts to reconcile doctrine but in shared commitments to practice: though doctrine and tradition may divide, it is service in the name of a common good, a higher good, which will unite.

\section{Acknowledgements Competing interests}

The author declares that she has no financial or personal relationships which may have inappropriately influenced her in writing this article.

\section{References}

Baker, C.R. \& Reader, J. (eds.), 2009, Entering the new theological space: Blurred encounters of faith, politics and community, Ashgate, Farnham.

Ballard, P., 1992, 'Can theology be practical?', Contact: The Interdisciplinary Journal of Pastoral Studies 109, 3-11.

Barth, K., 1928, The word of God and the word of Man, transl. D. Horton, Hodder \& Stoughton, London.

Bass, D., Cahalan, K., Miller-McLemore, B., Nieman, J. \& Scharen, C., 2016, Christian practical wisdom: What it is and why it matters, Wm. B. Eerdmans, Grand Rapids, MI.

Bass, D. \& Dykstra, C., 2008, For life abundant: Practical theology, theological education, and Christian ministry, Wm. B. Eerdmans, Grand Rapids, MI.

Beaudoin, T. 2008, Witness to dispossession: The vocation of a postmodern theologian, Orbis, Maryknoll, NY.

Beaudoin, T., 2016, 'Why does practice matter theologically?', in B.J. Miller-McLemore \& J.A. Mercer (eds.), Conundrums in practical theology, pp. 8-32, Brill, Leuven.

Bennett, Z., 2013, Using the bible in practical theology, Ashgate, London.

Bennett, Z. \& Graham, E., 2008, 'The Professional Doctorate in Practical Theology: Developing the researching professional in practical theology in higher education Journal of Adult Theological Education 5(1), 34-52. https://doi.org/10.1558/ jate2008v5i1.33

Bennett, Z. \& Rowland, C., 2016, In a glass darkly: The bible, reflection and everyday life, SCM, London.

Bevans, S., 2014, 'Contextual theology and practical theology', in K. Cahalan \& G. Mikoski (eds.), Opening the field of practical theology: An introduction, pp. 45-59, Rowman \& Littlefeld, New York.

Boff, L. \& Boff, C., 1987, Introducing liberation theology, Orbis, Maryknoll, NY.

Boyd, R., 2007, The witness of the Student Christian Movement: Church ahead of the church, SPCK, London.

Browning, D. S., 1991, Fundamental practical theology, Fortress, Minneapolis, MN.

Campbell, A., 1990, 'The nature of practical theology', in D.B. Forrester (ed.), Theology and practice, pp. 10-20, Epworth Press, London.

Dyson, A.O., 1983, 'Pastoral theology: Towards a new discipline', Contact: The Interdisciplinary Journal of Pastoral Studies 78, 2-8. https://doi.org/10.1080/135 20806.1983.11759497
Farley, E., 1983, Theologia: The fragmentation and unity of theological education, Fortress, Philadelphia, PA.

Ganzevoort, R.R. \& Roeland, J., 2014, 'Lived religion: The praxis of practical theology', International Journal of Practical Theology 18(1), 91-101. https://doi. org/10.1515/ijpt-2014-0007

Graham, E., 1989, 'The pastoral needs of women', Contact: The Interdisciplinary Journal of Pastoral Studies 100, 23-25.

Graham, E., 1990, 'Feminism, pastoral theology and the future', Contact: The Interdisciplinary Journal of Pastoral Studies 103, 2-9.

Graham, E., 1995, Making the difference: Gender, personhood and theology, Mowbray, London.

Graham, E., 1996, Transforming practice: Pastoral theology in an age of uncertainty, Mowbray, London.

Graham, E., 2000, 'Practical theology as transforming practice', in S. Pattison \& J.W. Woodward (eds.), The Blackwell reader in pastoral and practical theology, pp.104-117, Blackwell, Oxford.

Graham, E., 2013, 'Is practical theology a form of 'Action Research'?', International Journal of Practical Theology 17(1), 1-31. https://doi.org/10.1515/ijpt-2013-0010

Graham, E., Walton, H. \& Ward, F., 2005, Theological reflection: Methods, SCM, London.

Grenz, S., 1993, Revisioning evangelical theology, Inter-Varsity Press, Downers Grove, IL.

Groome, T.H.,1987, 'Theology on our feet: A revisionist pedagogy for healing the gap between academia and ecclesia', in L.S. Mudge \& J.N. Poling (eds.), Formation and reflection: The promise of practical theology, pp. 55-78, Fortress Press, Philadelphia, PA.

Harding, S., 1991, Whose science? Whose knowledge? Thinking from women's lives, Cornell University Press, Ithaca, NY.

Hiltner, S., 1958, Preface to pastoral theology, Abingdon Press, Nashville, TN.

Isgandarova, N., 2014, 'Practical theology and its importance for Islamic theological studies', Ilahiyat Studies 5(2), https://doi.org/10.12730/13091719.2014.52.109

May, M., 1995, A body knows: A theopoetics of death and resurrection, Continuum, New York.

Mercer, J.A., 2016, 'Interdisciplinarity as a Practical Theological Conundrum', in B.J. Miller-McLemore \& J.A. Mercer (eds.), Conundrums in practical theology, pp. 163-189, Brill, Leuven.

Miller-McLemore, B., 1994, Also a mother: Work and family as theological dilemma, Abingdon, Nashville, TN.

Miller-McLemore, B., 2011, 'Introduction: The contributions of practical theology', in B. Miller-McLemore (ed.), Wiley-Blackwell companion to practical theology, pp. 1-20, Wiley-Blackwell, Oxford.

Moon, J., 2006, Learning journals, Routledge-Falmer, London.

Nieman, J., 2002, 'Attending locally: Theologies in congregations', International Journal of Practical Theology 6(2), 198-225. https://doi.org/10.1515/ijpt.2002.6.2.198

Pattison, S.,1989, 'Some straw for the bricks: A basic introduction to theological reflection', Contact: The Interdisciplinary Journal of Pastoral Studies 100, 2-9. https://doi.org/10.1080/13520806.1989.11759678

Pattison, S., 2000, Shame: Theory, therapy, theology, Cambridge University Press, Cambridge.

Pattison, S. \& Lynch, G., 2005, 'Practical and pastoral theology', in D.F. Ford \& R. Muers (eds.), The modern theologians, 3rd edn., pp. 408-425, Blackwell, Oxford.

Rajput, A.H., 2015, 'Muslim chaplains in higher education', Practical Theology 8(3-4), 227-244. https://doi.org/10.1080/1756073X.2015.1126688

Schön, D.A., 1983, The reflective practitioner, Basic Books, New York.

Stoddart, E., 2014, Advancing practical theology: Critical discipleship for disturbing times, SCM, London.

Stringer, E.T., 2007, Action research, 3rd edn., Sage, London.

Swinton, J., 2012, 'Where is your church?', in P. Ward, (ed.), Perspectives on ecclesiology and ethnography, pp. 71-92, Wm B Eerdmans, Grand Rapids, MI.

Swinton, J. \& Mowat, H., 2016, Practical theology and qualitative research, 2nd edn., SCM, London.

Tanner, K., 1997, Theories of culture: A new agenda for theology, Fortress, Minneapolis, MN. Tatlow, T., 1933, The story of the Student Christian Movement, SCM, London.

Tertullian, 1956, 'The Prescriptions against Heretics', in S.L. Greenslade (ed.), Early Latin Theology (Library of Christian Classics V), transl. S.L. Greenslade, pp. 21-64, SCM, London.

Wainwright, G., 2005, 'Does doctrine still divide?', Ecclesiology 2(1), 11-34. https:// doi.org/10.1177/1744136605056576

Walton, H., 2014, Writing methods int theological reflection, SCM, London.

Walton, H., 2105, Not Eden: Spiritual life writing for this world, SCM, London.

Ward, F., 2004, 'The messiness of studying congregations using ethnographic methods', in M. Guest, K. Tusting, \& L. Woodhead (eds.), Congregational studies in the UK, pp. 125-138, Ashgate, Aldershot.

Ward, P., 2012, 'Introduction', in P. Ward (ed.), Perspectives on ecclesiology and ethnography, pp. 1-10, Wm B. Eerdmans, Grand Rapids, MI. https://doi. org/10.7208/chicago/9780226873190.003.0001 